\title{
EFFECT OF FEEDING STRAWBERRY (Fragariax ananas) VINES HAY ON DIGESTIBILITY, PHYSIOLOGICAL CASE AND MILK PRODUCTION OF LACTATING DAMASCUS GOATS UNDER HOT CONDITIONS IN EGYPT
}

\author{
H.M.F. Galal, M.A.M. Abdel-Hafez, T. Deraz, A.A. El-Zawahry and A.M. Hussein \\ Animal Production Research Institute, Agriculture Research Center, Ministry of Agriculture, Giza, \\ Egypt
}

(Received 27/1/2016, Accepted 3/3/2016)

\section{SUMMARY}

$\mathrm{T}$ The present study was planned to evaluate the nutritive values of strawberry vine hay and the possibility of inclusion this residues as a source of protein and energy in lactating goats under hot conditions of the year and the effect of this residues on physiological status, blood components, milk yield and components. Twenty eight Damascus healthy lactating does (aged 3 - 4 years and weighed 35$40 \mathrm{~kg}$ were divided into four similar groups according to weight, (7 lactating does in each) to investigate the effect of replacing $0 \%, 30 \%, 70 \%$ and $100 \%$ from berseem hay by strawberry vine hay on dray matter basis(G1, G2, G3 and G4) plus concentrate feed mixture to cover 100\% NRC requirements. Four digestibility trials were carried out to evaluate the four rations using. 12 mature bucks (3 in each)for digestibility trials. Ambient air temperature (AT) and relative humidity (RH \%) were recorded at the times of carrying out the Maximum and minimum temperatures were recorded. Temperature-humidity index (THI) was estimated. Thermoregulatory parameters were recorded biweekly with blood sample. Milk samples were obtained every week, daily milk yield and milk components were determined. Feed conversion and economical efficiency were calculated. Results showed that the lowest values of feed intake as $\mathrm{g} / \mathrm{h} / \mathrm{d}$ was recorded by G4, while the other groups (G1, G2 and G3) were nearly similar. The G2 had the highest values of Relative intake (\% of body weight) and $\mathrm{g} \mathrm{DMI} / \mathrm{Kg} \mathrm{W}^{0.75}$. Digestion coefficients of experimental rations showed that the $\mathrm{OM}$, $\mathrm{CP}$, EE, CF and NFE digestibility were higher in G2 and G3 than in G1 and G4. The feeding value as TDN were significantly higher in G2 than G1 and G4 and the difference between G1 and G3 was not significant, while DCP value of G2 was insignificantly higher than G1 and significantly higher than G3 and G4. The effects of feeding type on physiological measurements showed that the differences among hair surface temperature in all groups were not significant, while hair deep temperature (HDT), skin temperature and rectal temperature were significantly higher in G4 and G3 than G1 and G2 respectively, while the differences between G1 and G2 or G3 and G4 were not significant. Ear temperature in G1 and G2 were significantly lower than in G3 and G4, while the differences between G1 and G2 or G3 and G4 were not significant. Pulse rate and respiration rate of G2 was significantly lower than other groups, but the differences between G1 and G3 were not significant while the G4 was significantly higher than other groups. GOT (AST) and GPT (ALT) of G2 blood serum was significantly lower than other groups. The highest values were recorded in G1 and G4, while the differences between G1 and G3 were not significant. Total protein and albumin was significantly higher in G2 than other groups, while the differences among other groups were not significant. Calcium and phosphorus in G2 blood plasma was significantly higher than in other groups. The highest average daily milk yield and 4\% fat Corrected Milk (FCM) showed in G2, while the lowest value recorded in G4. Milk yield of G1 and G3 were nearly similar. The differences of chemical composition of milk among all groups were not significant. The best feed conversion (Kg DMI and $\mathrm{Kg}$ TDN / Kg FCM) were recorded with G2, while the bad feed conversion were recorded with G4. The highest economical efficiency was showed in G3 then followed G2, G4 and G1, respectively.

Keywords: strawberry vine, Damascus goats, physiological status, blood, milk

\section{INTRODUCTION}

In Egypt, animals are suffering from shortage of feeds especially during summer season which they almost depend on grains, concentrate feed mixtures and crop by-products mainly wheat and rice straw and little amounts of berseem hay. The rising costs of concentrate feeds (grains and protein supplements in particular) have led to significant increase in animal feed cost. The annual feed requirements for animal 


\section{Galal et al.}

wealth in Egypt are about 14 million tons of total digestible nutrients (TDN). The shortage of animal feeds was calculated to be approximately 3.1 million tons of TDN (Fayed et al., 2009). According to this problem growing attention is focused on the use of crop by-products, agricultural residues, wastes of fruits and vegetables for ruminant feeding which could be considered as a significant trend to alleviate the acute shortage of feedstuffs in Egypt and most developing countries, as well as diminishing the environmental pollution (AbouSelem and Bendary, 2005). In Egypt, about 25 million tons of agricultural by products are annually produced (Ministry of Agriculture and Land Reclamation, 2008). Utilization of agricultural vines residues can partly alleviate the gap between animal nutritional requirements and available feed stuffs and thus it is so necessary to investigate. In perspective, including local agricultural by-products into ruminant diets could reduce the feed cost and turn increase the economical efficiency of livestock production (Borhami and Yacout, 2001). In recent study, Galalet al.(2015) found that 25\% from CP of lambs rations could be replacement by CP of strawberry vines hay, since it increases daily gain and improves the economic efficiency in growing lambs. In the chemical composition, Galal et al. (2014) and Omar et al., (2011) showed that the strawberry vines hay had higher NFE\% and digestible energy and lower $\mathrm{CP} \%, \mathrm{CF} \%$ and $\mathrm{NDF} \%$ than berseem hay in rabbits. There is a limited literature on using strawberry residues in feeding ruminant, therefore there is an extreme need for more studies on using these residues in ruminant feeding specially goats. Goats had received very little attention as an important livestock species. However, their importance as a potential source of meat and milk has been recently realized, since they can play an important role in this respect. Moreover, goats are considered more tolerant to heat stress compared to dairy cows because of their greater sweating rate and lower body weight:surface ratio, allowing greater heat dissipation (Salama et. al., 2013). Goats with production demands are susceptible to heat stress in spite of heat resistant characteristics. Depression of feed intake and reduction in production are commonly observed in heat-stressed goats. Upper critical temperatures for goats in maintenance are $25^{\circ}$ to $30{ }^{\circ} \mathrm{C}$., but this has not been fully established for growing and lactating goats, $(\mathrm{Lu}, 1989)$. Goat's milk was reported to exhibit high digestibility and certain therapeutic effects in human subjects (Haenlein, 2004).

Damascus goat is considered a dual-purpose animal (meat and milk). Damascus goats are considered a seasonal breeder, and the breeding season starts in late August and extends through mid-December (Mavrogenis, et al., 2006). Damascus goat such as all farm animals in Egypt are suffering from shortage of feeds especially in suckling and lactating period especially in months may, June and July under hot periods of the year.

\section{MATERIALS AND METHODS}

Animals: The present study was carried out at El Gemmaiza Experimental Station, located in mid Nile Delta, Department of sheep and goats research belonging to Animal Production Research Institute, Ministry of Agriculture, Egypt. Twenty eight Damascus healthy lactating does (aged 3 - 4 years and weighed $35-40 \mathrm{~kg}$ after weaning were divided into four similar groups according to weight (7 lactating does in each). Lactating goat groups were housed in concrete pens, partially asbestos roofed in semi-open sheds during the experimental period. The surface area of each semi pen shed $8 \times 28$ meters each pen $(7 \times$ 8 meters) were surrounded by brick walls of two meters height, while the north, east and coast wall were height 4.5m.Digestibility trials were conducted using 12 mature bucks ( 3 in each ) in complete randomized design to evaluate the four treatments. The mature bucks weaing $50 \mathrm{~kg}$ approximately and were individually kept in metabolic cages. The chemical analysis were carried out according to the methods of A.O.A.C (1996).

Experimental procedure: The four experimental goats were fed concentrate feed mixtures (CFM) and roughage at the rate 1:1 to cover their requirements according to NRC (1981) as the follows:

First group as control (G1) was fed CFM and berseem hay (100\%).

Second group (G2) was fed CFM and mixture of berseem hay (70\%) and strawberry vines hay (30\%).

Third group (G3) was fed CFM and mixture of berseem hay (30\%) and strawberry vines hay (70\%).

Fourth group (G4) was fed CFM and strawberry vines hay (100\%).

The CFM composed of $37.4 \%$ wheat bran, $27 \%$ yellow corn, $12.5 \%$ soybean meal (44\% CP), $10.0 \%$ decorticated cottonseed cake, $5 \%$ rice bran, $4 \%$ sugarcane molasses, $3 \%$ limestone, $1 \%$ sodium chloride and $0.1 \%$ vitamin and minerals premix. 
Four digestibility trials were conducted at the last month of the feeding trial to evaluate the digestibility and feeding values of the experimental rations. A proximate analysis of the diets and feces were carried out according to A.O.A.C. (1996).

Ambient air temperature (AT) and relative humidity (RH\%) were recorded biweekly at the times of carrying out the physiological measurements. Maximum and minimum temperatures were recorded using mercury thermometer to the nearest $0.1^{\circ} \mathrm{C}$. Relative humidity was recorded using hair-hygrometer to the nearest $1 \%$. Temperature-humidity index (THI) was estimated according to equation of Livestock Poultry Heat Stress Index (1990) and modified by Marai et al. (2000) as follows: $\mathrm{THI}=\mathrm{db}{ }^{\circ} \mathrm{C}-\{(0.31-0.31 \mathrm{RH})$ $\left.\left(\mathrm{db}{ }^{\circ} \mathrm{C}-14.4\right)\right\}$ where $\mathrm{db}{ }^{\circ} \mathrm{C}=$ dry bulb temperature in Celsius and $\mathrm{RH}=\mathrm{RH} \% / 100$. Then, the obtained values of THI were classified as follows : $>22.2=$ absence of heat stress, $22.2-<23.3=$ moderate heat stress, $23.3-<25.6=$ severe heat stress and 25.6 and more $=$ very severe heat stress. The averages of ambient temperatures and relative humidity values and THI were estimated monthly.

Thermoregulatory parameters: Temperatures of rectal, skin, hair surface), hair depth and ear and rats of pulse and respiration as a physiological measurements of goats were measured every week. Rectal temperature was measured to the nearest $0.1^{\circ} \mathrm{C}$ by inserting electronic thermometer probe to the depth of 5-6 cm into the rectum. Hair, and hair depth, skin and ear temperatures were measured by alcohol thermometer. In addition, pulse rate (number of pulses/min) and respiration rate (was recorded by a hand counter, which counts the frequency of the flank movement per minute).

Blood samples: Blood Samples biweekly were collected with thermoregulatory parameters from the jugular vein of each lactating goat into glass tubes contained heparin as anticoagulant. Blood samples were centrifuged at $3000 \mathrm{rpm}$ for 15 minutes to obtain plasma and stored at $-20^{\circ} \mathrm{C}$ until plasma analyses. GOT and GPT in blood serum were determined by using kits SaluceaHaansberg 194874 NJEttenLeur.The Netherlands . Concentration of total protein and albumin in plasma were estimated using Biuret reaction and bromocresol green reagent kites, respectively, manufactured by Diamond Diagnostic Company (Egypt). However, globulin concentration was calculated by subtraction of albumin values from their corresponding total protein values. Calcium and inorganic phosphorus was measured by direct method with ammonium molybdate reagent kites manufactured by Diamond Diagnostic Company, Egypt.

Milk determination: At morning and evening, milk yield were determined daily per does from birth and to the end of lactation period. Samples of milk at morning and evening $(20 \mathrm{ml})$ were collected biweekly in the same day of physiological measurements and blood samples. Milk samples were analysis for total solids (TS), fat, solids not fat (SNF), total nitrogen (TN), lactose, salt, density and freeze point by using digital Lactoscans, Milk analyzer, Wide LCD display-4 lines $\times 16$ characters. 8900 Nova Zagora, Bulgaria.

Statistical analysis: The statistical analysis for was computed using analysis of variance procedures. Significant differences between means were separated by Duncan Multiple Rang test procedures described in SAS (1995). Data were analyzed using the following mathematical model:

$\mathrm{Y}_{\mathrm{ij}}=\mu+\mathrm{T}_{\mathrm{i}}+\mathrm{e}_{\mathrm{ij}}$

$\mu=$ the overall mean for the trial under consideration

$\mathrm{T}_{\mathrm{i}}=$ the effect of the treatments

$\mathrm{e}_{\mathrm{ij}}=$ random residual error.

\section{RESULTS AND DISCUSSION}

\section{Chemical composition:}

Chemical composition data in Table (1) showed that the percentages of OM, CP, EE, were markedly higher values in CFM. The EE and NFE were higher in strawberry vines (SV) than in Berseem hay (BH). The $\mathrm{CF}$ in $\mathrm{BH}$ were higher than in SV. On the other hand, CP was lower in SV than in BH. The chemical composition of strawberry vines agreed with that obtained by Omar et al. (2011), Galal et. al. (2014) and Galal et. al. (2015). On comparison with some straws and stover, CP and NFE contents of strawberry vines hay was higher than those of bean straw, corn stalks and rice straw and CF had opposite trend (Mehrez et. al., 2001).The chemical composition of experimental ration were nearly similar in most nutrient contents except $\mathrm{CP}$ and $\mathrm{CF}$ in $\mathrm{G} 1, \mathrm{G} 2$ and $\mathrm{G} 3$ rations were slightly higher than in G4. 
Galal et al.

Table (1): Chemical composition of lactating goats rations during experimental period.

\begin{tabular}{llllllll}
\hline \multirow{2}{*}{ Item } & & \multicolumn{7}{c}{ Chemical composition (on DM \%basis) } \\
\cline { 5 - 8 } & DM & OM & CP & EE & CF & NFE & Ash \\
\hline CFM & 91.01 & 88.64 & 14.64 & 3.11 & 12.40 & 58.49 & 11.36 \\
Berseem hay (Bh) & 87.17 & 88.05 & 13.24 & 1.71 & 30.19 & 42.91 & 11.95 \\
Strawberry vines (SV) & 84.84 & 88.42 & 8.98 & 2.31 & 17.86 & 59.27 & 11.58 \\
Four experimental rations: & & & & & & & \\
G1 & 89.15 & 88.31 & 13.98 & 2.36 & 21.31 & 50.66 & 11.69 \\
G2 & 88.81 & 88.78 & 13.62 & 2.53 & 19.32 & 53.31 & 11.22 \\
G3 & 88.32 & 88.60 & 12.65 & 2.68 & 16.85 & 56.42 & 11.40 \\
G4 & 87.80 & 88.45 & 11.75 & 2.69 & 15.35 & 58.66 & 11.55 \\
\hline
\end{tabular}

DM=Dry matter,$O M=$ Organic matter,$C P=$ Crude protein,$E E=$ Ether extract,$N F E=$ Nitrogen free extract

\section{Feed intake, digestion coefficient and nutritive values:}

The lowest values of feed intake as $\mathrm{g} / \mathrm{h} / \mathrm{d}$ was recorded by G4, while the other groups (G1,G2 and G3) were nearly similar. The G2 had the highest values of Relative intake (\%Body weight) and $\mathrm{g} \mathrm{DMI} / \mathrm{Kg}$ $\mathrm{W}^{0.75}$ as shown in Table (2). The relative intake ranged from 4.35 to $4.61 \%$ of live body weight. However, goats have a higher dry matter intake (DMI) compared to lactating dairy cattle (about $3 \%$ in dairy cattle) therefore it consumed high level from roughage compared with cattle. DMI generally peaks about 8-12 weeks after kidding of goats.

Digestion coefficient of experimental rations (Table 2) showed that the OM, CP, EE, CF and NFE digestibility were higher in G2 and G3 than in G1 and G4. Galal et al. (2015) showed that OM, CP, EE and NFE digestibility were higher with increased Strawberry vines hay up to 50\% when replaced $\mathrm{CP}$ of CFM of sheep rations. However, the digestion coefficients of nutrients except NFE in this study were higher than that obtained by Galal et al. (2015) by sheep. The feeding values as TDN were significantly higher in G2 than G1 and G4 and the difference between G1 and G3 was not significant, while DCP value of G2 was insignificantly higher than G1 and significantly higher than G3 and G4. Similar results of TDN and DCP were obtained by Galal et al. (2015). Etman and Soliman (1999) found that DCP values of peanut tops hay + CFM rations ranged from 8.4 to $9.5 \%$, while TDN ranged from 70.3 to $75.1 \%$. Maraiet al. (2000) found that TDN and DCP in growing lamb rations containing CFM + berseem hay and wheat straw were 56.17 and $8.58 \%$ respectively.

\section{Environmental conditions:}

The calculated of temperature - humidity index (THI) values during late of pregnant (March) ,suckling and lactation period (from April to August) were recorded sever in March and very sever during April to August (Table 3), indicted that animal exposed to very sever heat stress during lactation period.

\section{Physiological measurements:}

The effects of feeding type on physiological measurements are shown in Table 4. The differences among hair surface temperature (HST) in all groups (G1, G2, G3 and G4) were not significant, while hair deep temperature (HDT), skin temperature (ST) and rectal temperature (RT) were significantly higher in G4 and G3 than G1 and G2 respectively, while the differences between G1 and G2 or G3 and G4 were not significant. Ear temperature (ET) in G1 and G2 were significantly lower than in G3 and G4, while the differences between $\mathrm{G} 1$ and $\mathrm{G} 2$ or G3 and G4 were not significant. Pulse rate (PR) and respiration rate (RR) of G2 was significantly lower than other groups, but the differences between G1 and G3 were not significant, the G4 was significantly higher than other groups. Rectal temperature is another important indicator of thermal balance and may be used to assess the adversity of thermal environment. A rise of $1^{\circ} \mathrm{C}$ or less in rectal temperature is enough to reduce performance in most livestock species, which makes it a sensitive indicator of physiological response to heat stress (Nardoneet.al.,2010and Berman,2011). All data lie within the normal rectal temperatures $\left(38.3\right.$ to $39.9^{\circ} \mathrm{C}$ under thermoneutral conditions is normal, while that of $42^{\circ} \mathrm{C}$ and above is considered dangerous (Thwaites, 1985). Generally, the lowest values of HDT, ST, ET, PR, RR and RT were recorded with G2 which fed concentrate mixtures $+70 \%$ Berseem 
hay and 30\% Strawberry vines hay and the highest values were recorded in groups G4 which fed concentrate mixture $+100 \%$ Strawberry vines hay.

Table (2): Feed intake, digestion coefficient and nutritive values of goats fed experimental rations.

\begin{tabular}{|c|c|c|c|c|}
\hline \multirow{2}{*}{ Item } & \multicolumn{4}{|c|}{ Experimental groups } \\
\hline & G1 & G2 & G3 & G4 \\
\hline Live body weight (Kg) & 35.46 & 34.17 & 36.09 & 33.71 \\
\hline \multicolumn{5}{|l|}{ Feed intake (g/h/d.) } \\
\hline Feed concentrate mixture & 873 & 882 & 891 & 836 \\
\hline Clover hay & 873 & 617 & 267 & 0 \\
\hline Strawberry vines hay & 0 & 265 & 624 & 836 \\
\hline Total (as fed) & 1746 & 1764 & 1782 & 1672 \\
\hline Total (as DM) & 1557 & 1567 & 1573 & 1467 \\
\hline Relative intake (\%) & 4.41 & 4.61 & 4.37 & 4.35 \\
\hline $\mathrm{g} \mathrm{DMI} / \mathrm{Kg} \mathrm{W}^{0.75}$ & 107.2 & 110.9 & 106.8 & 104.9 \\
\hline \multicolumn{5}{|l|}{ Digestion coefficients } \\
\hline DM & 66.43 & 64.62 & 65.17 & 67.43 \\
\hline $\mathrm{OM}$ & 68.49 & 76.12 & 73.15 & 68.16 \\
\hline $\mathrm{CP}$ & 63,29 & 70.30 & 67.32 & 64.91 \\
\hline EE & 68.42 & 73.50 & 70.42 & 67.15 \\
\hline $\mathrm{CF}$ & 55.06 & 60.12 & 57.10 & 53.15 \\
\hline NFE & 72.76 & 80.19 & 76,90 & 71.93 \\
\hline \multicolumn{5}{|l|}{ Nutritive values (\%) } \\
\hline TDN & $61.06^{\mathrm{b}}$ & $68.13^{\mathrm{a}}$ & $65.78 \mathrm{ab}$ & $62.04^{\mathrm{b}}$ \\
\hline DCP & $8.85^{\mathrm{ab}}$ & $9.57^{\mathrm{a}}$ & $8.52^{\mathrm{b}}$ & $7.62^{\mathrm{c}}$ \\
\hline \multicolumn{5}{|l|}{ Feed units intake } \\
\hline TDN, g /Kg W ${ }^{0.75}$ & 65.44 & 75.57 & 70.29 & 65.05 \\
\hline $\mathrm{DCP}, \mathrm{g} / \mathrm{Kg} \mathrm{W}^{0.75}$ & 9.50 & 10.61 & 9.10 & 8.01 \\
\hline
\end{tabular}

Table (3): Average monthly of ambient temperatures ,relative humidity (\% ) and THI values during different months of experimental period.

\begin{tabular}{lllll}
\hline \multirow{2}{*}{ Experimental period } & \multicolumn{3}{c}{ Environmental conditions } \\
\cline { 2 - 5 } & AT ${ }^{\circ} \mathrm{C}$ & RH \% & THI & Stress status \\
\hline Marsh & 26.00 & 55.00 & 24.38 & Sever heat stress \\
April & 28.00 & 65.00 & 26.52 & very sever heat stress \\
May & 32.00 & 60.00 & 29.82 & very sever heat stress \\
June & 36.00 & 55.00 & 32.99 & very sever heat stress \\
July & 39.00 & 55.00 & 35.57 & very sever heat stress \\
August & 38.50 & 50.00 & 34.76 & very sever heat stress \\
\hline
\end{tabular}

$A T^{\circ} \mathrm{C}=$ air ambient temperature, $\mathrm{RH} \%=$ relative humidity, $T H I=$ Temperature Humidity Index and SH=status of heat stress 
In this connection, the highest values in digestion coefficient of OM, CP, EE, CF and NFE and nutritive values as TDN and DCP in G2 may be affected with physiological case of animals. The increase in energy and protein values in G2 than other groups during hot condition may be due to the decrease in hair deep, ear, skin and rectal temperatures and rats of pulse and respiration of G2. During heat exposure, Battacharya and Hussain (1993) concluded that heat stress resulted in a reduced ME and nitrogen retention. Ames and Brink (1977) reported that increase energy requirement by thermally-stressed animals significantly reduced the protein deficiency ratio. However, the effect of high roughage diet on rectal temperature was more evident with the high ambient temperature (Murad et. al.,1994). In the same trend, Pulse rate and respiration rate were significantly higher in G4 than other groups. These results lead to increase in heat load in does in G4.The pulse rate reflects primarily the homeostasis of circulation along with the general metabolic level, it increase on expouser to high environmental temperature (Aboul$\mathrm{Nga}, 1987)$. The increase in RR is one of common physiological responses of animals when ambient temperature increases which is aimed to dissipate the extra heat load in order to maintain normal body temperature (Sudarman and Ito (2000). The heat stress in summer is characterized by increase in respiration rate. In Damascus goats, Habeeb et. al. (1993 and 2016) found that the respiration and pulse rats, skin and rectal temperatures was significantly increased at ambient temperatures above $30^{\circ} \mathrm{C}$ ).

Table (4): Physiological parameters in lactating goats fed the experimental rations during hot condition seasons of the year.

\begin{tabular}{lcccc}
\hline \multirow{2}{*}{ Physiological measurement } & \multicolumn{4}{c}{ Experimental group } \\
\cline { 2 - 5 } & $\mathrm{G} 1$ & $\mathrm{G} 2$ & $\mathrm{G} 3$ & $\mathrm{G} 4$ \\
\hline Hair surface temperature ${ }^{\circ} \mathrm{C}$ & $39.29 \pm 0.49$ & $38.70 \pm 0.49$ & $39.81 \pm 0.49$ & $40.15 \pm 0.53$ \\
Hair deeptemperature ${ }^{\mathrm{o}} \mathrm{C}$ & $37.71 \pm 0.34^{\mathrm{bc}}$ & $37.25 \pm 0.34^{\mathrm{c}}$ & $38.30 \pm 0.34^{\mathrm{ab}}$ & $38.86 \pm 0.37^{\mathrm{a}}$ \\
Skin temperature ${ }^{\circ} \mathrm{C}$ & $36.71 \pm 0.26^{\mathrm{bc}}$ & $36.33 \pm 0.26^{\mathrm{c}}$ & $37.27 \pm 0.26^{\mathrm{ab}}$ & $37.71 \pm 0.28^{\mathrm{a}}$ \\
Ear temperature ${ }^{\circ} \mathrm{C}$ & $35.71 \pm 0.23^{\mathrm{b}}$ & $35.54 \pm 0.23^{\mathrm{b}}$ & $36.60 \pm 0.23^{\mathrm{a}}$ & $36.40 \pm 0.25^{\mathrm{a}}$ \\
Pulse rate, ppm & $81.82 \pm 0.80^{\mathrm{b}}$ & $78.71 \pm 0.80^{\mathrm{c}}$ & $77.61 \pm 2.59^{\mathrm{b}}$ & $87.25 \pm 2.79^{\mathrm{a}}$ \\
Respiration rate, rpm & $73.18 \pm 2.59^{\mathrm{bc}}$ & $68.04 \pm 2.59^{\mathrm{c}}$ & $77.61 \pm 2.59^{\mathrm{b}}$ & $87.25 \pm 2.59^{\mathrm{a}}$ \\
Rectal temperature ${ }^{\circ} \mathrm{C}$ & $39.42 \pm 0.09^{\mathrm{bc}}$ & $39.20 \pm 0.09^{\mathrm{c}}$ & $39.5 \pm 0.09^{\mathrm{ab}}$ & $39.69 \pm 0.09^{\mathrm{a}}$ \\
\hline
\end{tabular}

${ }^{a, b, c}$ Means in the same row with different superscripts differ significantly at $P<0.05$

\section{Blood constituents:}

Heat stress has resulted in reduced feed intake and low metabolic rate. These responses are related to thyroid activity which directly influence the gut motility passage rate of the digesta. Changes in the quality and quantity of food alter the intensity of the metabolic heat load (Mahr-Un-Nisa et al., 1999). GOT and GPT of G2 blood plasma was significantly lower than other groups. The highest values were recorded in G1 and G4 (Table 5), while the differences between G1 and G3 were not significant. The decrease in load on liver in G2 than in other groups may be due to quality mixture of berseem hay and strawberry vine hay under hot condition. Total protein and albumin was significantly higher in G2 than other groups, while the differences among other groups were not significant. The increase in total protein and albumin in G2 may be due to the increase in CP digestibility and DCP of G2 than other groups. The decrease in plasma protein could be due to decrease in protein synthesis as a result of decrease in anabolic hormone secretion (El-Masry and Habeeb, 1989) or due to protein catabolism to divert amino acids towards gluconeogenesis (Sejian et al., 2010b). The synthesis of plasma protein is markedly impaired when the supply of amino acids from the digestive process is not adequate (Hooda and Upadhyay, 2014 ).Calcium and phosphorus in blood plasma of G2 was significantly higher than in other groups. These increase may due to decrease in mineral secretion in urine. Increased body temperature and respiration rate are the most important signs for heat stress in goat. These include the aberration of oxidative stress and enzymatic dysfunction (David et al. 2001), electrolyte imbalances (West et al. 1991). Fayzaetal. 
(2011) found that heat stress caused decrease in calcium ( $\mathrm{Ca}$ ) by $20 \%$ in blood plasma of buffalo-calves exposed to heat stress $\left(40{ }^{\circ} \mathrm{C}\right.$ and $\left.87.5 \% \mathrm{RH}\right)$. Exposure of sheep to heat stress evokes a series of drastic changes in the biological functions, which include a decrease in feed intake efficiency and utilization, disturbances in water, protein, energy and mineral balances, enzymatic reactions, hormonal secretions and blood metabolites ( Marie et al., 2007).

Table (5): Blood components of lactating goats fed the experimental rations.

\begin{tabular}{lcccc}
\hline \multirow{2}{*}{ Blood component } & \multicolumn{3}{c}{ Experimental group } \\
\cline { 2 - 5 } & $\mathrm{G} 1$ & $\mathrm{G} 2$ & $\mathrm{G} 3$ & $\mathrm{G} 4$ \\
\hline GOT (U/L) & $15.76 \pm 0.71^{\mathrm{ab}}$ & $12.54 \pm 0.71^{\mathrm{c}}$ & $15.12 \pm 0.71^{\mathrm{b}}$ & $17.77 \pm 0.76^{\mathrm{a}}$ \\
GPT(U/L & $8.85 \pm 0.59^{\mathrm{ab}}$ & $6.63 \pm 0.58^{\mathrm{c}}$ & $8.35 \pm 0.58^{\mathrm{b}}$ & $10.35 \pm 0.64^{\mathrm{a}}$ \\
Total protein (g/dl) & $8.58 \pm 0.12^{\mathrm{b}}$ & $9.09 \pm 0.12^{\mathrm{a}}$ & $8.67 \pm 0.12^{\mathrm{b}}$ & $8.36 \pm 0.13^{\mathrm{b}}$ \\
Albumin (g/dl) & $4.09 \pm 0.08^{\mathrm{b}}$ & $4.34 \pm 0.08^{\mathrm{a}}$ & $4.11 \pm 0.08^{\mathrm{b}}$ & $3.92 \pm 0.08^{\mathrm{b}}$ \\
Globulin (g/dl) & $4.49 \pm 0.08^{\mathrm{b}}$ & $4.75 \pm 0.08^{\mathrm{a}}$ & $4.55 \pm 0.08^{\mathrm{ab}}$ & $4.42 \pm 0.08^{\mathrm{b}}$ \\
Albumin/Globulin, ratio & $0.92 \pm 0.02^{\mathrm{a}}$ & $0.92 \pm 0.02^{\mathrm{a}}$ & $0.90 \pm 0.02^{\mathrm{a}}$ & $0.91 \pm 0.02^{\mathrm{a}}$ \\
Calcium (mg/dl) & $8.82 \pm 0.14^{\mathrm{b}}$ & $9.44 \pm 0.14^{\mathrm{a}}$ & $8.64 \pm 0.14^{\mathrm{b}}$ & $8.23 \pm 0.15^{\mathrm{c}}$ \\
Phosphorus (mg/dl) & $3.82 \pm 0.08^{\mathrm{b}}$ & $4.17 \pm 0.08^{\mathrm{a}}$ & $3.86 \pm 0.08^{\mathrm{b}}$ & $3.74 \pm 0.08^{\mathrm{b}}$ \\
\hline
\end{tabular}

$\overline{a, b, c}$ Means in the same row with different superscripts differ significantly at $P<0.05$

\section{Milk production and its components:}

The highest average daily milk yield and 4\% fat Correct Milk (FCM) showed in G2 then followed G3, while the lowest value recorded in G4 (Table 6). Milk yield of G1 and G3 were nearly similar. The increasing milk production of G2 may be due to the high percent of nutrient digestibility and consequently TDN and DCP intakes which reflected on milk production, moreover the improvement in physiological cases of animals. However, the differences of chemical composition of milk among all groups were not significant as shown in Table (6). Generally, the milk composition lie within the chemical composition of goats milk as determined by Hafsa et.al., (2014).

Table (6): Average daily milk yield and its components of goats fed the experimental rations.

\begin{tabular}{lcccc}
\hline \multirow{2}{*}{ Item } & \multicolumn{4}{c}{ Experimental group } \\
\cline { 2 - 5 } & $\mathrm{G} 1$ & $\mathrm{G} 2$ & $\mathrm{G} 3$ & $\mathrm{G} 4$ \\
\hline Milk yield (gm/h/d) & 685.4 & 808.8 & 691.6 & 555.7 \\
$4 \%$ fat Correct Milk(FCM) & 676.2 & 779.7 & 686.4 & 571.6 \\
Milk composition & & & & \\
Total solids \% & $13.12^{\mathrm{a}} \pm 0.22$ & $12.64^{\mathrm{a}} \pm 0.22$ & $12.97^{\mathrm{a}} \pm 0.22$ & $13.29^{\mathrm{a}} \pm 0.22$ \\
Fat \% & $4.00^{\mathrm{a}} \pm 0.16$ & $3.76^{\mathrm{a}} \pm 0.16$ & $3.95^{\mathrm{a}} \pm 0.16$ & $4.19^{\mathrm{a}} \pm 0.16$ \\
Solids not fat \% & $9.12^{\mathrm{a}} \pm 0.08$ & $8.86^{\mathrm{a}} \pm 0.08$ & $9.02^{\mathrm{a}} \pm 0.08$ & $9.10^{\mathrm{a}} \pm 0.08$ \\
Protein \% & $3.38^{\mathrm{a}} \pm 0.03$ & $3.24^{\mathrm{ab}} \pm 0.03$ & $3.28^{\mathrm{ab}} \pm 0.03$ & $3.34^{\mathrm{ab}} \pm 0.03$ \\
Lactose \% & $5.02^{\mathrm{a}} \pm 0.05$ & $4.89^{\mathrm{a}} \pm 0.05$ & $4.96^{\mathrm{a}} \pm 0.05$ & $5.00^{\mathrm{a}} \pm 0.05$ \\
Salt \% & $0.74^{\mathrm{ab}} \pm 0.01$ & $0.72^{\mathrm{b}} \pm 0.01$ & $0.74^{\mathrm{ab}} \pm 0.01$ & $0.74^{\mathrm{a}} \pm 0.01$ \\
Density & $32.42^{\mathrm{a}} \pm 0.28$ & $31.52^{\mathrm{b}} \pm 0.28$ & $32.15^{\mathrm{ab}} \pm 0.28$ & $32.19^{\mathrm{ab}} \pm 0.28$ \\
Freeze point C ${ }^{\mathrm{a}}$ & $-0.60^{\mathrm{b}} \pm 0.01$ & $-0.57^{\mathrm{a}} \pm 0.01$ & $-0.58^{\mathrm{ab}} \pm 0.01$ & $-0.59^{\mathrm{ab}} \pm 0.01$ \\
TVFA,ml N/10 NaOH $/ 100$ & $6.50^{\mathrm{ab}} \pm 0.14$ & $6.42^{\mathrm{b}} \pm 0.14$ & $6.30^{\mathrm{c}} \pm 0.14$ & $6.64^{\mathrm{a}} \pm 0.14$ \\
ml milk & & & & \\
\hline
\end{tabular}

$\overline{a, b, c}$ Means in the same row with different superscripts differ significantly at $P<0.05$.

TVA=total volatile fatty acids. 


\section{Feed conversion and economical efficiency:}

The best feed conversion (Kg DMI and Kg TDN / Kg FCM) were recorded with G2, while the bad feed conversion were recorded with G4. The DCP conversion as $\mathrm{kg} / \mathrm{Kg}$ FCM were nearly equal in all groups (Table 7). The feed conversion of lactating goats is affected by the milk yield, fat corrected milk, feed intake, dietary components, fiber content, roughage: concentrate ratio and digestion coefficients of feed nutrients. The highest value of feed intake cost was recorded with G1, then followed G2, G3 and G4, respectively caused the high price berseem hay when compared with Strawberry vines hay. The highest economical efficiency was showed in G3 then followed G2, G4 and G1, respectively as shown in Table 7. The economical efficiency is affected by Cost of feed intake, total milk yield and price of milk yield.

Table (7): Feed conversion andeconomical efficiency of goats fed the experimental rations.

\begin{tabular}{|c|c|c|c|c|}
\hline \multirow{2}{*}{ Item } & \multicolumn{4}{|c|}{ Experimental groups } \\
\hline & G1 & G2 & G3 & G4 \\
\hline Average daily feed intake $(\mathrm{kg} / \mathrm{h} / \mathrm{d})$ & 1.746 & 1.764 & 1.782 & 1.672 \\
\hline \multicolumn{5}{|l|}{ Feed Conversion: } \\
\hline $\mathrm{Kg}$ DMI/Kg FCM & 2.30 & 2.01 & 2.29 & 2.57 \\
\hline Kg TDNI/Kg FCM & 1.41 & 1.37 & 1.51 & 1.59 \\
\hline $\mathrm{Kg}$ DCPI/Kg FCM & 0.20 & 0.19 & 0.20 & 0.20 \\
\hline \multicolumn{5}{|l|}{ Economic Study } \\
\hline Cost of rations (LE/ton) & 1625 & 1512 & 1362 & 1250 \\
\hline Fed $\operatorname{cost}(\mathrm{L} . \mathrm{E} / 1 \mathrm{Kg} 4 \%$ FCM $)$ & 4.20 & 3.42 & 3.54 & 3.66 \\
\hline Cost of feed intake (LE/h/d) & 2.84 & 2.67 & 2.43 & 2.09 \\
\hline Price of milk yield (LE/h/d) & 2.70 & 3.12 & 2.75 & 2.29 \\
\hline Economical efficiency,\% & 0.95 & 128.8 & 139.5 & 109.6 \\
\hline
\end{tabular}

\section{CONCLUSION}

According to the circumstances of this study, It could be concluded that the mixture of berseem hay and strawberry vines hay especially 70:30 ratio in diet of lactating goats under hot conditions led to improved digestion coefficients and nutritive values, also improved physiological case and milk production and improved the economical efficiency.

\section{REFERENCES}

Abu-El- Naga, A.I.(1987).The role of aldosterone in improving productivity of heat -stressed farm animals with different techniques. Ph.D. Thesis, Faculty of Agriculture, Zagazig University, Zagazig, Egypt.

Abou-Selem, I .A. and M. Bendery (2005). Feedstuff resources in Egypt, Sources and maximization of its utilization. Animal Production Research Institute, Second Conference \& Regional Symposium on Buffalo Production ,Sakha, Kafr El- Sheikh, Egypt.

Ames, D.R., and D.R. Brink (1977). Effect of temperature on lamb performance and protein efficiency ratio.J.Anim.Sci.,44:136-40.

Association of Official Analytical Chemists (AOAC) (1996). Official methods of analysis, $16^{\text {th }}$ ed. ,Washington, D.C, USA.

Bhattacharya ,A.N., and F. Hussain(1993).Intake and utilization of nutrients in sheep fed different levels of roughage under heat stress .J.Anim.Sci.,71:1761-6. 
Berman. A. ( 2011). Invited review: Are adaptations present to support dairy cattle productivity in warm climates? J. Dairy Sci. 94: 2147-2158.

Borhami, B.E.A. and M.H.M. Yacout (2001). Is the animal protein essential for better utilization of plant protein in ruminants? Egyptian J. Nutr.and Feeds (Special Issue) $4: 25$

David, M.H., R.B Garry, W.O. Larry, X. Linjing , D.M. Ronald.,,V.G. Carl (2001). Mechanisms of circulatory and intestinal barrier dysfunction during whole body hyperthermia. American Journal of Physiology, 280: H509-H521.

El-Masry, K.A. and A. A. Habeeb (1989). Thyroid Function in lactating Friesian cows and water buffaloes under winter and summer. Proc. 3rd Egypt. Brit. Conf. Anim. Fish and Poult. Prod. 2, 613620 .

Etman, K. E. I. and E.S. Soliman (1999). Effect of feeding peanut (ArachisHypogaea L.)tops with different levels of concentrates on performance of growing lambs. Egyptian J. of Nutrition and Feeds, 2 (Special Issue): 223-231.

Fayed, Afaf M., M.A. El-Ashry, and Hind A. Aziz (2009). Effect of feeding olive tree pruning byproducts on sheep performance in Sinai .World J.Agric.Sci ; 5(4):436 - 445.

Fazya, O. I., G.Ashour, M. M.Yousef and M. M. Shafie (2011). Responses of hematology, blood metabolites, mineral ions and hormonal profile to heat stress for Egyptian buffalo- calves. Egypt. J. Agric. Res., 89 (3), 2011

Galal, H.M.F.; M.A.El-Menniawy; M.H. Abo-Fadel; A.A. Khir and Safaa N.Abdel -Azeam (2014). Some nutritional studies on using strawberry (Fragaria $\times$ Ananas) vine as hay in rabbit ration.J.Animal and Poultry Prod., Mansoura Univ., Vol. 5 (12) :635-647.

Galal, H. M. F. ; M. A. El-Menniawy ; M. H. Abo El-Fadel ; A. A. Khir and Safaa N. Abdel-Azeam ( 2015). Using strawberry (Fragariaananas) vine hay in rations ofgrowing lambs..J. Animal and Poultry Prod., Mansoura Univ. Vol. 6 (1), 43 - 53.

Habeeb ,A., A. Abou El-Naga, A.I. and H.M. Yousef (1993). Influence of exposure to high temperature on daily gain, feed efficiency and blood components of growing male Californian rabbits. Egyptian Journal of Rabbit Science, 3: 73-80.

Habeeb, A. A. M., M. A. M.Abdel-Hafez, E. S. H. EL-Gohary and O. A. Salama (2016). Effect of $\mathrm{AD}_{3}$ E vitamins injection on age and weight of weaning and reproductive activity of goats 2 - Effect of $\mathrm{AD}_{3} \mathrm{E}$ vitamins injection and diurnal variations on physiological response and reproductive activity of goat bucks exposed to direct solar radiation of hot summer season in Egypt. J. Animal and Poultry Prod. Mansoura Univ., 6(12): 719-739.

Haenlein, G.F.W.( 2004). Goat milk in human nutrition. Small Ruminant Res., 51: 155.

Hafsa F. H. Youssef, M. E. El-Gendy, E. O. H. Saifelnasr, Heba A. El-Sanafawy and Fatma El-Saba (2014).Relationship between body confirmation and milk yield and composition in Zaraibi and Damascus goats.Egyptian Journal of Sheep \& Goat Sciences, 9 (3), P: 83-94.

Hooda, O.K. and R.C. Upadhyay (2014). Physiological Responses, Growth Rate and Blood Metabolites under Feed Restriction and Thermal Exposure in Kids.Journal of Stress Physiology \& Biochemistry, Vol. 10 No. 2 2014, pp. 214-227.

Lu,C.D. (1989) . Effects of heat stress on goat production. Small Ruminant Research, 2: 151-162.

Mahr- Un-Nisa, M. Sarwar,Q. Bilal and M.A. Feroz ( 1999). Effect of temperature stress on nutrient utilization and different physiological function of ruminant animals.International Journal of Agriculture and Biology. 3:174-178.

Marai I.F.M., L.B. Bahgat, T.H. Shalaby and M.A.M. Abdel-Hafez (2000). Fattening performance, some behavioral traits and physiological reactions of male lambs fed concentrates mixture alone with or without natural clay under hot summer of Egypt. Annals of Arid Zone, 39, 449-460.

Marai , I.F.M., A.A. El-Darawany, A.Fadil, and M. A.M.Abdel-Hafez, (2007). Physiological traits as affected by heat stress in sheep. A review.Small Rumin. Res.71:1-12.

Mavrogenis, A.P., N.Y. Antoniades and R.W.Hooper (2006). The Damascus (Shami) goat of Cyprus. P. Kavvadias str., 1020 Nicosia, Cyprus . 


\section{Galal et al.}

Mehrez, A. Z., E. S. Soliman; M. Y. El-Ayek; E. A. El-Ayouty and M. E. El-Kholany (2001). Influence of roughage to concentrate ratio and type of roughage on digestibility, some rumen parameters and fiber fractions degradability of tested rations with ruminants. Egyptian J. Nutrition and feeds .4 (Special issue): 193-207.

Ministry of Agriculture and land Reclamation Report (2008). Agriculture economics. Bull, Center Dept. Agric ., Economic, Cairo, Egypt.

Murad, H.M.,T.M. El-Bedawy, M.M.Shafie and S.M.Salem (1994). Effect of heat stress and dietary roughage level rumen function, nutrient utilization and water turnover by native Egyptian sheep. Egyptian Journal of Animal Production, $\underline{31}$ (supplemented ):361-371.

Nardone, A., B. Ronchi, N. Lacetera, M.S. Ranieri and U. Bernabucci ( 2010). Effects of climate changes on animal production and sustainability of livestock systems. Livest.Sci.130:57-69.

NRC (1981).National Research Council. Effect of Environment on Nutrient Requirement of Domestic Animals. National Academy Press Washington, DC

Omar ,H.A.A., F.A.F. Ali and A.M. Ibrahim (2011). Strawberry By-Products as a partial replacement of clover hay in rabbit diets. American-Eurasian J. Agric. Environ. Sci., 11(6):815-823.

Salama, A.A.K.,G.Caja, B.Hamzaoui, B.Badaoui, A.Castrocosta, ,D.A.E., Facanha, M.M. Guilhermino and Z. Bozzi, (2013). Different levels of response to heat stress in dairy goats Small Ruminant Research ,P.7.

Sejian, V.,R.S. Srivastava and V.P.Varshney (2010). Effect of short term thermal stress on biochemical profile in Marwari goats.Ind.Vet.J.78:175-194.

SAS (1995). SAS Users Guide :Statistics Version $5^{\text {th }}$ Edition SAS Institute Inc. Cary .NC.

Sudarman, A. and T.Ito (2000). Heat production and thermoregulatory responses of sheep fed roughage proportion diets and intake levels when exposed to a high ambient temperature. Asian -Aus. J.Anim.Sci.,13,No.5:625-629.

Thwaites, C.J. (1985). Physiological responses and productivity in in sheep.In Stress Physiology in Livestock .edited by M.K.Yousef,II:pp 25-39.CRC Press, Inc. Boca Raton, Florida, USA.

West, J.W., B.O. Yullinix and G. Sandifer (1991). Changing dietary electrolyte balance for dair cows in cool and hot environments. Journal Dairy Science, 74: 1662-1674. 
حسن محم فؤاد جلال ، محمد أحمد ححمد عبدالحافظ ، طارق عبدالوهاب دراز ، أحمد الظواهرى و أحمد ححم عبدالمجيد حسين .

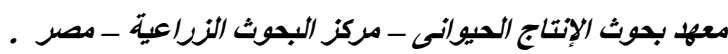

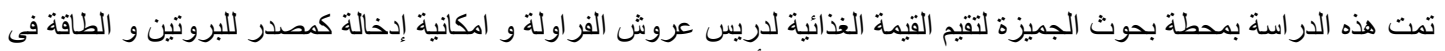

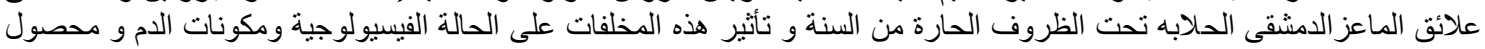
اللبن و تركييه .

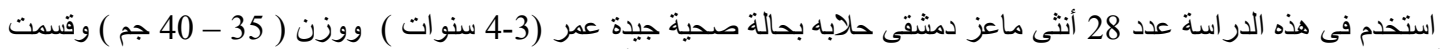

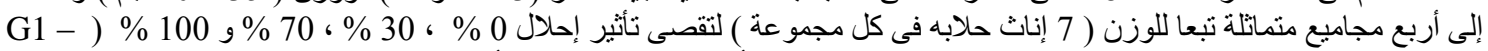
( G 2 - G3 - G4

الاحتياجات 100 \% من NRC استمرت تجربة التغذية مدة 181 يوم .

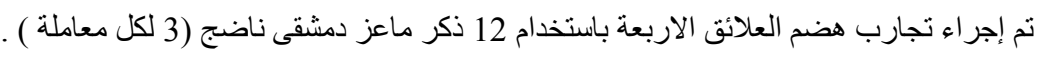
أهم النتائج المتحصل عليها: سجلت المجموعة الر ابعة ( G4 ) أقل كمية عليقة مأكوله بينما باقى العلائق متماتلة .

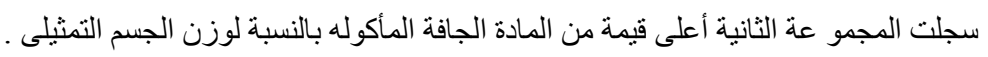

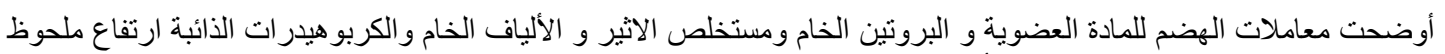
فى المجمو عة الثانية و الثالثة عن المجمو عة الأولى و الرابعة.

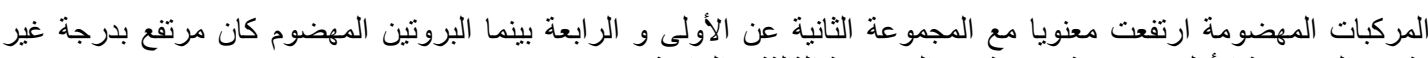
معنوية عن المجموعة الأولى و بدرجة معنوية عن المجمو عة الثالثة و الرابعة . كما أوضحت الدراسة

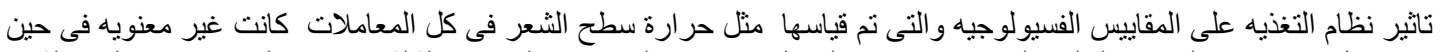

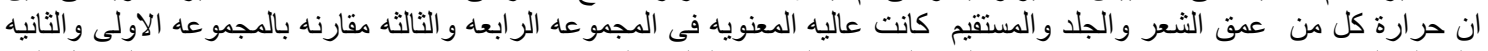

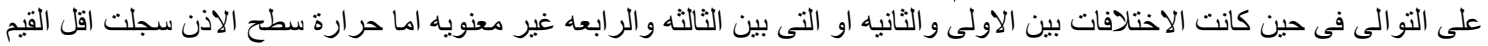

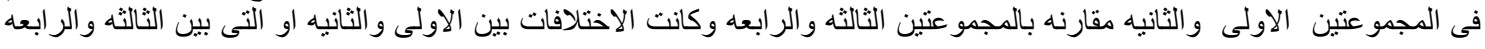
غير معنويه.

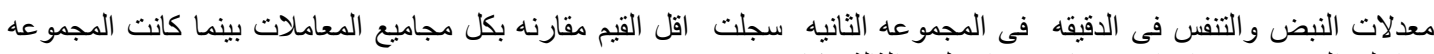

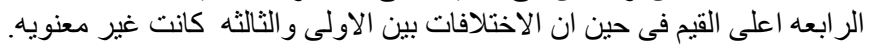

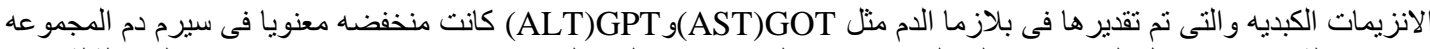

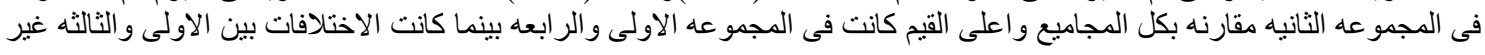
معنويه البروتين الكلى و الالبيومين سجل اعلى التقديرات فى بلازما الدم للمجموعه الثانيه بينما الاختلافات بين باقى المجموعات كانت غير معنويه. القايم المقدرة للمعادن فى بلازما الدم مثل الكالسيوم والفوسفور للمجمو عه الثانيه سجلت اعلى القيم مقارنه بباقى مجاميع المعاملات الاخرى. سجلت المجمو عة الثانية اعلى انتاج لبن يومى معدل 4 \% دهن وكانت أقلهم المجموعة الرابعة والأختلافات بين المجموعات فى تركيب الللبن كانت غير معنوية .

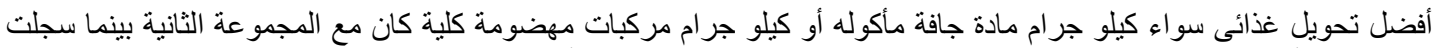

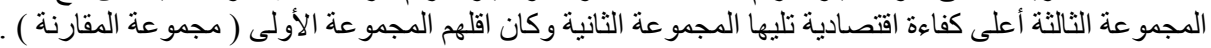

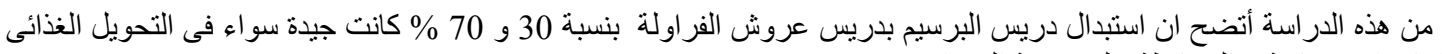

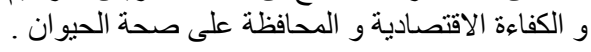

